\section{High performance lightweight noise barrier with carbon fibre reinforced concrete}

HENRIK L. FUNKE - Institute of Lightweight Structures, Technische Universität Chemnitz, Germany - henrik.funke@mb.tu-chemnitz.de

SANDRA GELBRICH - Institute of Lightweight Structures, Technische Universität Chemnitz, Germany - sandra.gelbrich@mb.tu-chemnitz.de

LoTHAR KROLL - Institute of Lightweight Structures, Technische Universität Chemnitz, Germany - lothar.kroll@mb.tu-chemnitz.de

Érkezett: 2015. 03. 09. - Received: 09. 03. 2015. " http://dx.doi.org/10.14382/epitoanyag-jsbcm.2015.14

\begin{abstract}
High-strength concrete elements exhibiting low system weight and great slenderness can be created with a large degree of lightweight structure using textile-reinforced concrete (TRC) slab and a shell with very high level of sound absorption. The system was developed with the objective of lowering system weight, and then implemented operationally in construction. Arising from the specifications placed on the load-bearing concrete slab, the followings were developed: an adapted fine-grain concrete matrix was assembled, a carbon warp-knit fabric was modified and integrated into the fine concrete matrix, a formwork system at prototype scale was designed enabling noise barriers to be produced with an application-oriented approach and examined in practically investigations within the context of the project. Substantial decrease in weight of the load-bearing concrete slab's system was possible, which led to a decrease in transport and assembly costs. Keywords: textile-reinforced concrete, noise barrier, high-performance concrete, durability
\end{abstract}

Henrik FUNKE has been research associate at the Chair of Lightweight Structures and Plastic Processing at Chemnitz University of Technology since 2010. He is engaged in the research area of lightweight construction in civil engineering and works with fibre reinforced mineral construction materials. Henrik Funke studied ceramic, glass and construction materials technology between 2004 and 2009 at Freiberg Technical University of Mining and Technology.

Sandra GELBRICH studied civil engineering at Bauhaus-University Weimar and has been research associate at Chemnitz University of Technology since 2002. Sandra Gelbrich gained here doctorate in 2008 and was associated academic councillor in 2009. She has been head of the research department for lightweight construction in civil engineering at the Chair of Lightweight Structures and Plastic Processing since 2009.

Lothar KROLL is the Head of the professorship Lightweight Structures and Plastic Processing at Chemnitz University of Technology and the director of the Cetex Institute for Textile and Processing Machines in Chemnitz since 2006 and 2007 respectively. He is the Chief Executive Officer of Federal Cluster of Excellence "MERGE" since 2012 and the Head of Fraunhofer Plastic Center Oberlausitz since 2013.

\section{Introduction}

Noise is a consequence of increasing mobility and has a negative effect on both human beings and the environment. The continuous rise in traffic density, which grew by more than 70 percent on motorways between 1980 and 2012 [1], has led to greater noise emissions. Today, this makes sound protection measures more important than ever. It does not matter whether these noise barriers are for major roads, motorways or high-speed sections. Such systems are very complex and contain restrictions with regards to load-bearing capacity, serviceability and functionality. Alongside acoustic and mechanical specifications including durability, economic and ecological aspects additionally come to the fore. The objective is savings on resources not just based on optimizing weight and minimizing manufacturing costs but also leading to decreasing expenditure for transport and assembly.

In Germany, about 50 percent of noise barriers are made of concrete. They are mostly composed of a load-bearing layer made from steel reinforced concrete and a noise-absorbing facing concrete shell set up on one or both sides and made from lightweight concrete. The usual material thickness with the loadbearing concrete layer is about 12 to $15 \mathrm{~cm}$ due to the concrete coverage needed in terms of passive protection against corrosion. Utilising textile reinforced concrete in this case offers great potential in reducing weight and constructing in a resourceefficient and sustainable manner. Textile reinforced concrete is an innovative high-performance composite material consisting of fine concrete matrix and textile reinforcement $[2,3]$. The development of this new type of composite material has made a construction method available which utilizes reinforcement that is generally not susceptible to corrosion due to environmental influences (e.g. air humidity and chloride) $[4,5]$. The concrete cover needed in steel reinforced concrete construction can thus be substantially reduced by employing textile reinforced concrete $[6,7]$. Just a few millimeters minimum concrete cover is necessary to safeguard the transfer of bonding forces between the fine concrete matrix and the textile reinforcement [8]. This means that thin-walled, free-formed surfaces can be created with a great degree of lightweight structure that feature low system weight and great slenderness.

This paper reports the development of a noise barrier, which consists of a load-bearing component made of textile reinforced concrete and a noise-absorbent component made of a lightweight concrete. An important part of this work is durability and so the lifespan of the noise barrier.

\section{Materials and methods}

\subsection{Components for load- bearing and noise-absorbent concretes}

Table 1 illustrates the qualitative and quantitative composition of the load-bearing concrete and the noise-absorbent concrete. The load-bearing concrete contains, besides type CEM I $52.5 \mathrm{R}$ Portland cement according to EN 206, pozzolanic fly ash and silica fume as binding agents (Table 1), which have a positive action on both fresh and hardened concrete characteristics in respect of sedimentation stability, durability and mechanical strength. Two quartz sands and dolomite powder were utilized as aggregate or filler. The alkali resistant (AR) glass fibres, which lower the propensity to shrinkage cracking and can enhance first crack tensile strength in the concrete, are $12 \mathrm{~mm}$ long and have a length mass of 45 tex. The high-performance superplasticiser employed has a 30 percent by weight proportion of polycarboxylate ether (PCE). The noise-absorbent concrete has a monodisperse (single particle) aggregate made of round expanded clay in a fraction of 0 to $2 \mathrm{~mm}$. 


\begin{tabular}{lcc} 
Component & $\begin{array}{c}\text { Load-bearing } \\
\left(\mathbf{k g} / \mathbf{m}^{\mathbf{3}}\right)\end{array}$ & $\begin{array}{c}\text { Absorber } \\
\left(\mathbf{k g} / \mathbf{m}^{\mathbf{3}}\right)\end{array}$ \\
\hline White cement 52.5 R & 495 & 250 \\
\hline Amorphous alumosilicate & 150 & - \\
\hline Quartz sand 0/2 & 310 & - \\
\hline Quartz sand 0/1 & 900 & - \\
\hline Expanded clay & - & 970 \\
\hline Dolomite powder $\left(\mathbf{x}_{\mathbf{5 B}}=\mathbf{7 0} \boldsymbol{\mu \mathbf { m } )}\right.$ & 190 & - \\
\hline Water & 210 & 150 \\
\hline AR-glass fibres $\mathbf{( 1 2} \mathbf{~ m m , ~ i n t e g r a l ) ~}$ & 14 & - \\
\hline superplasticizers & 15 & - \\
\hline Water-binder-ratio & 0.38 & 0.60 \\
$\begin{array}{c}\text { Table 1. Composition of the fine grained concrete mix } \\
\text { 1. táblázat A vizsgált finomszemü betonok összetétele }\end{array}$ &
\end{tabular}

\subsection{Textile for textile reinforced concrete}

Two layers of a two-dimensional bidirectional warp-knit fabric of carbon were used for the reinforcement of TRC (Fig. 1). The warp and weft yarn had a length weight of $3300 \mathrm{~g} / \mathrm{km}$ (슬 3300 tex) and a tensile strength of $1576 \mathrm{MPa}$. The mesh size of the 15 mass percent impregnated warp-knit fabric (measured by thermogravimetry) was $10.8 \times 18.0 \mathrm{~mm}^{2}$. The warp and weft yarn consisted of 50000 carbon filaments with a diameter of $7 \mu \mathrm{m}$. The degree of reinforcement in concrete was approximately $1.1 \%$ by volume.

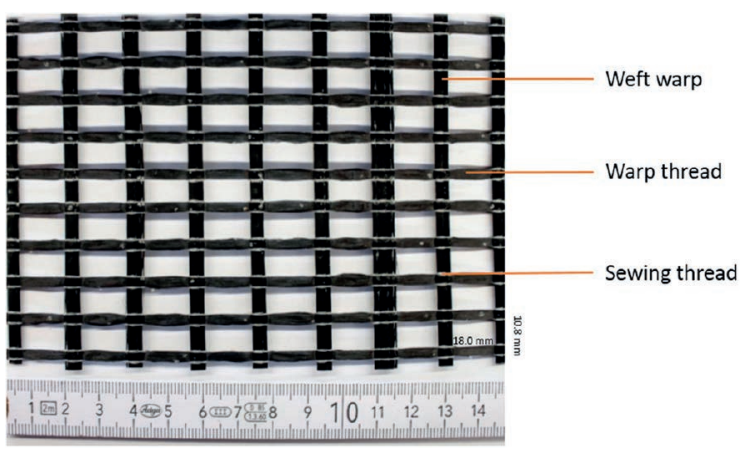

Fig. 1. Schematic of the bidirectional warp-knit fabric of carbon fibres

1. ábra. A kétirányban teherhordó szénszálas szövet sémája

\begin{tabular}{lcccc} 
component & $\begin{array}{c}\text { mixing } \\
\text { technology }\end{array}$ & $\begin{array}{c}\text { mixing } \\
\text { power in \% }\end{array}$ & $\begin{array}{c}\text { mixing time } \\
\text { in s }\end{array}$ \\
\hline 1st & $\begin{array}{c}\text { binders }+ \\
\text { aggregates }\end{array}$ & concurrent & 15 & 60 \\
\hline 2nd & $75 \%$ of water & sequence & 35 & 90 \\
\hline 3rd & super plasticizer & sequence & 35 & 60 \\
\hline 4th & residual water & sequence & 40 & 30 \\
\hline 5th & AR-glass fibres & sequence & 40 & 30
\end{tabular}

Table 2. Mixing parameters for fine grained concrete

2. táblázat A finomszemü betonok keverési paraméterei

\subsection{Test Specimens}

Several plates $\left(50 \times 50 \mathrm{~cm}^{2}\right)$ were prepared for the test specimens. In a first step, the absorber concrete was mixed. Thereafter, the fresh absorber concrete was poured into the mold. After this, the fine grained concrete was mixed with the intensive mixer R05T by Erich. The mixing parameters are shown in Table 2. Subsequently, the fresh fine grained concrete was applied on the absorber concrete (Fig. 2.a). Finally, the test plates were demolded after 24 h (Fig. 2.b).
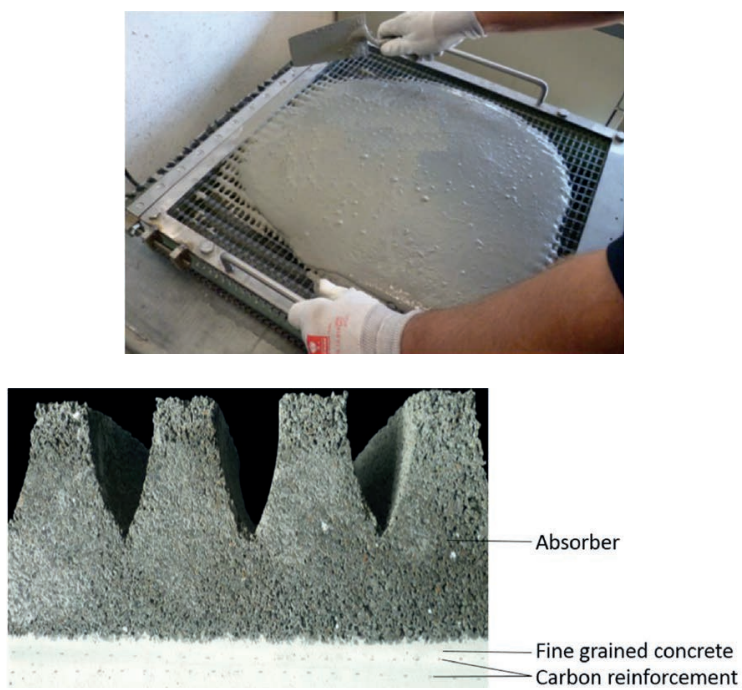

Fig. 2. Application of fine grained concrete (a) and demolded test plate (b) 2. ábra. A finomszemü beton alkalmazása (a) és a kizsaluzott elem képe (b)
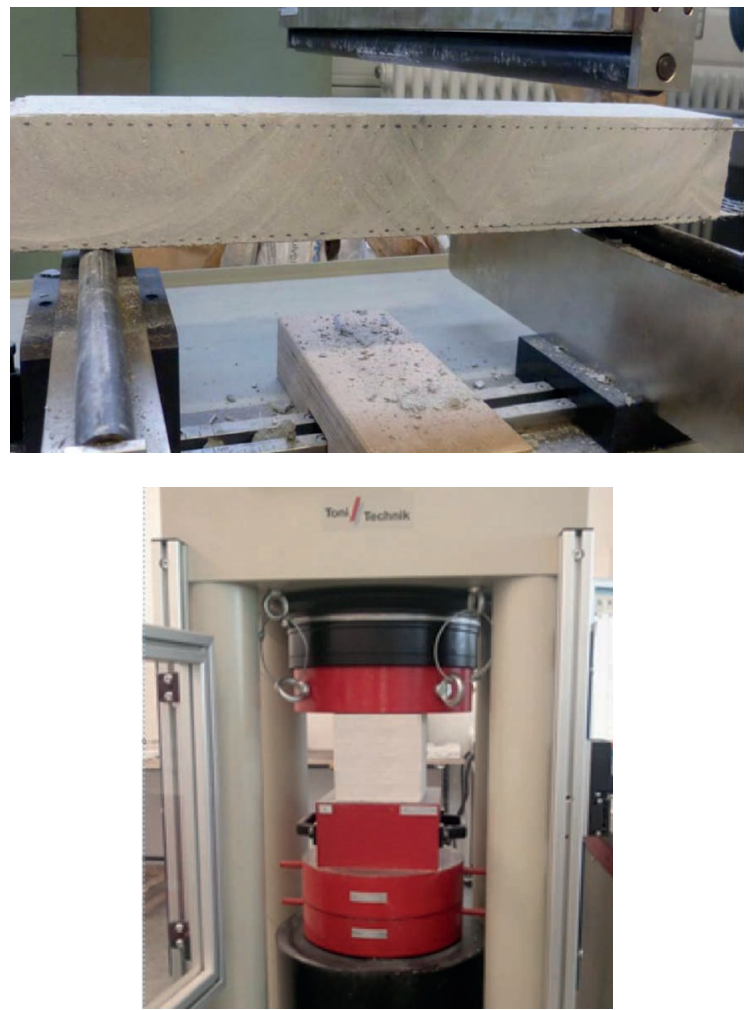

Fig. 3. Determination of 3-point bending tensile strength (a) and compressive strength (b) 3. ábra. Harmadpontos hajlitóvizsgálat elrendezése (a) és nyomószilárdság vizsgálat (b)

\subsection{Test Specimens Test set-up for TRC and absorber}

The samples for the tests to be performed on the hardened concrete were stored dry, according to EN 12390-2. The 3-point bending tensile strength (Fig. 3.a) was determined by means of the Toni Technik ToniNorm with samples which measured $225 \times 50 \times 15 \mathrm{~mm}^{3}$ (length $\times$ width $\times$ height), based on $\mathrm{EN}$ 12390-5. The span width set was $200 \mathrm{~mm}$ and the load speed $100 \mathrm{~N} / \mathrm{s}$ constant. The compressive strength was determined 
by means of the Toni Technik ToniNorm (load frame $3000 \mathrm{kN}$ ) following EN 12390-3, with cubes having an edge length of $150 \mathrm{~mm}$ (Fig. 3.b). The pre-load was $18 \mathrm{kN}$.

To validate the durability of the fine grained concrete, the capillary suction of de-icing solution and freeze thaw test (CDF-Test) was measured by the Schleibinger FreezeThaw-Tester with standard agent solution according to the recommendations of RILEM TC 117-FDC (Fig. 4).

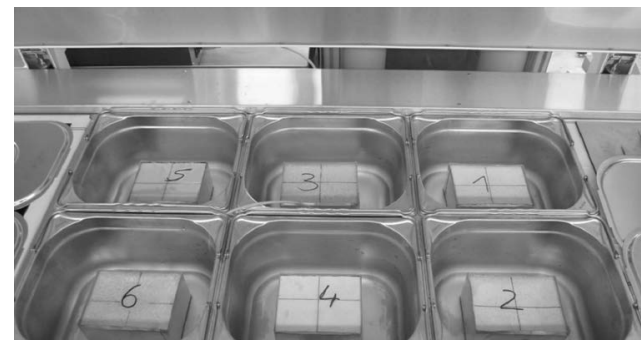

Fig. 4. Determination of the capillary suction of de-icing solution and freeze thaw test 4. ábra. Kapilláris sóoldat felszivás és fagyhámlás vizsgálata

\section{Results}

\subsection{Properties of fresh and hardened TRC}

Table 3 shows the fresh and hardened concrete characteristics after 28 days. The fresh fine grained concrete possessed great flowability (flow spread $640 \mathrm{~mm}$ ) and corresponded to flow class F6 according to EN 12350-5. Using an air content tester, air content of 2.7 volume percent and a gross geometric density of $2.31 \mathrm{~g} / \mathrm{cm}^{3}$ were determined in the fresh concrete. A shrinkage channel was utilized to determine the total shrinkage deformation at $0.68 \mathrm{~mm} / \mathrm{m}$. The reason for this high total shrinkage was the high binding agent content and the great chemical and autogenic strength of the hardened concrete at 28 days (gross density: $2.31 \mathrm{~g} / \mathrm{cm}^{3}$ ) was $83.7 \mathrm{MPa}$; it was $25 \mathrm{MPa}$ after 24 hours. The 3-point bending tensile strength of the unreinforced concrete was $11.73 \mathrm{MPa}$ after 28 days.

\begin{tabular}{lcc}
\multicolumn{1}{c}{ characteristic } & $\begin{array}{c}\text { fresh } \\
\text { concrete }\end{array}$ & $\begin{array}{c}\text { hardened } \\
\text { concrete }\end{array}$ \\
\hline geometric bulk density & $2.37 \mathrm{~g} / \mathrm{cm}^{3}$ & $2.31 \mathrm{~g} / \mathrm{cm}^{3}$ \\
\hline flow spread & $640 \mathrm{~mm}$ & - \\
\hline air content & $2.7 \mathrm{Vol} .-\%$ & - \\
\hline linear shrinkage & $0.91 \mathrm{~mm} / \mathrm{m}$ \\
\hline compressive strength & - & $83.7 \mathrm{MPa}$ \\
\hline 3-point bending tensile strength & - & $11.73 \mathrm{MPa}$ \\
Table 3. Properties of fresh and hardened fine grained concrete & \\
3. táblázat Frissbeton és szilárd beton jellemzók (finomszemü beton) &
\end{tabular}

In addition, the fine concrete exhibited great durability, which was verified through a successful CDF test with an average scaling of $912 \mathrm{~g} / \mathrm{m}^{2}$ and a relative dynamic modulus of elasticity of 100 percent after 28 freeze-thaw cycles (Table 4).

\begin{tabular}{lc}
\multicolumn{1}{c}{ test method } & test value \\
CDF test & $\mathrm{m}_{28}=113 \mathrm{~g} / \mathrm{m}^{3}$ \\
\cline { 2 - 2 } & $\mathrm{R}_{\mathrm{u}, 28}=100 \%$ \\
\hline
\end{tabular}

water penetration depth

$11 \mathrm{~mm}$

Table 4. Examinations of the durability of fine grained concrete

4. táblázat Tartóssági vizsgálatok a finomszemü betonon
Building in 2 layers of carbon meshes in with the flow of forces enabled the 3 point flexural strength to be enhanced to 24.51 MPa (Fig. 5). In this case, the first crack tensile strength was $11.21 \mathrm{MPa}$ (Fig. 5). By utilizing short fibres with a critical fibre volume content (fibres have a strengthening effect on the matrix) and prestressing the textile reinforcement, an increase in tension without slippage was observed in the concrete after macro-crack formation (see blue shading in Fig. 5), i.e. the bending tensile stress was transferred without loss of force from the concrete into the textile reinforcement. Integrating short fibres in the concrete generated a fine crack pattern with a positive action on durability.

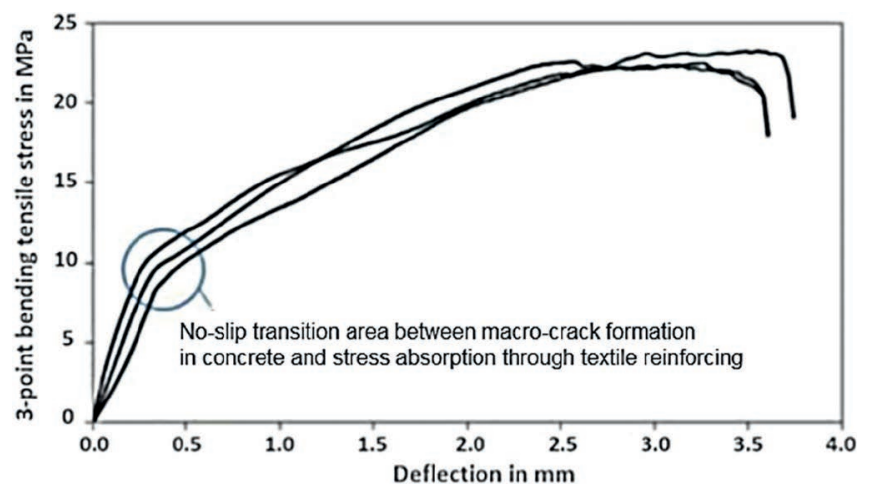

Fig. 5. Stress-deflection diagram

5. ábra. Feszültség-lehajlás diagram

\subsection{Noise-absorbent concrete}

The noise-absorbent concrete had a gross density of $1.31 \mathrm{~g} / \mathrm{cm}^{3}$ and a compressive strength of 16.0 MPa (Table 5). Dynamic modulus of elasticity of $17 \mathrm{GPa}$ was determined from the speed of sound using an ultrasonic measurement device. The degree of sound absorption was ascertained by means of the reverberation time procedure according to EN ISO 354:2003 with structured test specimens (Fig. 6.b). The results of this test showed that the degree of sound absorption is more than 0.7 at a frequency of $160 \mathrm{~Hz}$ (Fig. 6.a). The first local maximum sound absorption $(\alpha=1)$ was found at a frequency of $350 \mathrm{~Hz}$. The decrease in sound absorption between 600 and $1000 \mathrm{~Hz}$ after $800 \mathrm{~Hz}$ means that great sound particle velocity prevails in this area. These types of curve progressions occur comparatively often with mono-modular and porous aggregate materials. They are indicative of insufficient flow resistance adaptation. The result is that the noise absorber acts like a resonator. Based on these measurements, the noise absorbent shell met the conditions for sound group 4 (highly absorbent).

\begin{tabular}{lcc}
\multicolumn{1}{c}{ characteristic } & $\begin{array}{c}\text { fresh } \\
\text { concrete }\end{array}$ & $\begin{array}{c}\text { hardened } \\
\text { concrete }\end{array}$ \\
geometric bulk density & $1.53 \mathrm{~g} / \mathrm{cm}^{3}$ & $1.43 \mathrm{~g} / \mathrm{cm}^{3}$ \\
\hline flow spread & $650 \mathrm{~mm}$ & - \\
\hline air content & $11.5 \mathrm{Vol} . \%$ & 10.4 \\
\hline compressive strength & - & $16.9 \mathrm{MPa}$ \\
\hline 3-point bending tensile strength & - & $2.0 \mathrm{MPa}$
\end{tabular}

Table 5. Properties of fresh and hardened noise-absorbent concrete 5. táblázat Frissbeton és szilárd beton jellemzők (hangelnyelő beton) 

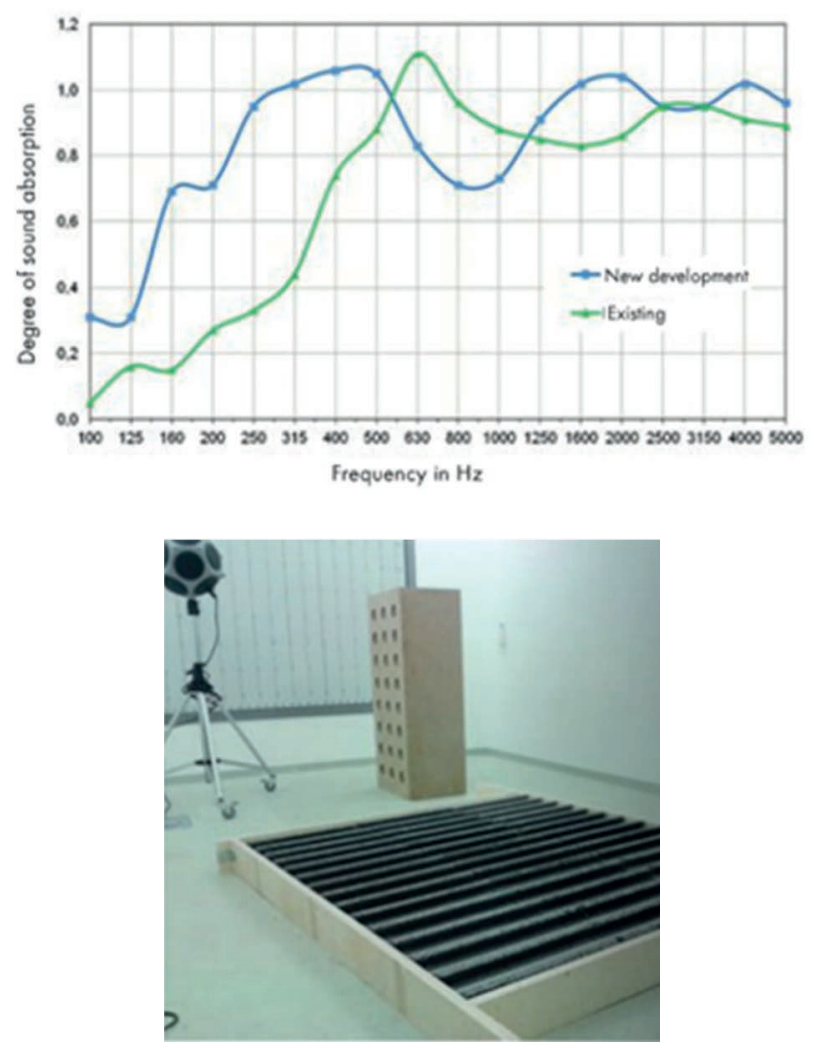

Fig. 6. Degree of sound absorption according to EN ISO 354 (a) Degree of sound absorption (b) Measurement in echo chamber

6. ábra. Hangelnyelés vizsgálata az EN ISO 354 szabvány szerint (a) Hangelnyelés mértéke (b) Mérés visszhang kamrában

\section{Conclusions}

At the completion of this project, a noise barrier was able to be implemented using textile-reinforced lightweight construction method under construction conditions. In the context of the present research and development project, a scientific basis was created for developing the materials: it was technically implemented in production, tested in numerous test series, adopted and practically investigated in the form of a prototype.

Integrating short fibres in the concrete generated a fine crack pattern with a positive action on durability, amongst other things. Taking the first crack computations into account, proof was furnished in mechanical investigations that the thickness of the textile-reinforced, load-bearing concrete slab can be reduced from $12 \mathrm{~cm}$ (steel reinforced concrete) to $5 \mathrm{~cm}$ (carbon reinforced concrete). Proof was also given of good post-cracking strength, low creep and shrinkage deformation, low susceptibility to cracking and excellent resistance to frost/ de-icing salt (exposure class XF4).

This new type of textile-reinforced noise barrier meets requirements as regards resource efficiency, cost reduction, sustainability, minimization of the system slab weight and a decrease in transport and assembly expenses in practice under construction conditions. The marginal conditions for manufacturing such noise barriers on an industrial scale in large quantities with high demands on equality are currently being created in preparation for its mass production and market launch. Beyond this, a key priority is obtaining general building authority approval or product approval.

\section{Acknowledgements}

This work was supported by the German Federation of Industrial Research Associations (AiF). The authors would like to acknowledge with gratitude the foundation's financial support.

\section{References}

[1] Lohre, D. - Bemecker, T. - Stock, W. (2012): ZF-Zukunftsstudie 2012, In: EuroTransport Media Verlags- und Veranstaltungs-GmbH, Stuttgart, $17 \mathrm{p}$.

[2] Curbach, M. - Scheerer, S. (2011): Concrete light - Possibilities and Visions. In: Šrůma, V. (Ed.): Proceedings of the fib Symposium Prague 2011: Concrete Engineering for Excellence and Efficiency, 8-10. June 2011, DVDROM, ISBN 978-80-87158-29-6, pp. 29-44.

[3] Brameshuber, W. (2006): Textile Reinforced Concrete, RILEM Report 36. State-of-the-Art Report of RILEM Technical Committee, TC 201-TRC

[4] Curbach, M. - Michler, H. - Weiland, S. - Jesse, D. (2008): Textilbewehrter Beton - Innovativ! Leicht! Formbar! BetonWerk International, Vol. 11, No. 5, pp. 62-72.

[5] Curbach, M. - Jesse, F. (2010): Verstärken mit Textilbeton. In K. Bergmeister, F. Fingerloos, J.-D. Wörner (Eds.), Betonkalender 2010, Teil 1, Abschn. VII. Berlin: Ernst \& Sohn

[6] Curbach, M. - Scheerer, S. (2012): Wie die Baustoffe von heute das Bauen von morgen beeinflussen. In: KIT (Hrsg.): Baustoffe und Betonbau - Lehren, Forschen, Prüfen, Anwenden, ISBN 978-3-86644-795-0., 2012, pp. 25-36.

[7] Funke, H. - Gelbrich, S. - Ehrlich, A. (2013): Development of a new hybrid material of textile reinforced concrete and glass fibre reinforced plastic. In: Hufenbach, W. A.; Gude, M.: Materials Science Engineering, Symposium B6 - Hybrid Structures. Procedia Materials Science, Vol. 2, pp. 103-110. http://dx.doi.org/10.1016/j.mspro.2013.02.013

[7] Mobasher, B. - Dey, V. - Cohen, Z. - Peled, A. (2014): Correlation of constitutive response of hybrid textile reinforced concrete from tensile and flexural tests. Cement and Concrete Composites, Vol. 53, pp. 148-161. http://dx.doi.org/10.1016/j.cemconcomp.2014.06.004

[8] Curbach, M. - Scheerer, S. - Hampel, T. - Schmidt, N. - Wellner, S. (2013): Structural Reassessment of Existing Road Bridges in Germany. In: IABSE Conference Rotterdam 2013 - Assessment, Upgrading and Refurbishment of Infrastructures. Conference Report, Vol. 99, IABSE, ISBN 978-3-85748123-9, pp. 420-421.

$\underline{\text { Ref.: }}$

Funke, Henrik L.- Gelbrich, Sandra- Kroll, Lothar: High performance lightweight noise barrier with carbon fibre reinforced concretes Építőanyag - Journal of Silicate Based and Composite Materials, Vol. 67, No. 3 (2015), 90-93. p. http://dx.doi.org/10.14382/epitoanyag-jsbcm.2015.14

Nagy teljesítőképességű könnyűbeton zajvédő fal szénszál erősítésű betonból

Nagy szilárdságú, kis önsúllyal rendelkezô, nagy karcsúságú textil-erôsítésû könnyúbeton lemez és nagy hangelnyelôképességú könnyúbeton héj kombinációját vizsgálja a cikk. A kutatás során kifejlesztésre került a finomszemú beton összetétele, a szénszál-erôsítésú szövet, a hangelnyelố héj zsaluzata. A fejlesztés eredményeként jelentôs önsúly csökkenést lehetett elérni, amely gazdaságos beépítést tesz lehetôvé.

Kulcsszavak: textil-erôsítésú beton, könnyúbeton, zajvédô fal, tartósság 